\title{
Upper Gastrointestinal Tract Cancer TNM Finding v8
}

National Cancer Institute

\section{Source}

National Cancer Institute. Upper Gastrointestinal Tract Cancer TNM Finding v8. NCI

Thesaurus. Code C133363.

A finding about one or more characteristics of upper gastrointestinal tract cancer, following the rules of the TNM AJCC v8 classification system. 